\title{
Cesarean Section in a Pregnant Woman with COVID-19: First Case in Portugal
}

\section{Parto por Cesariana em Grávida com COVID-19: 0 Primeiro Caso Descrito em Portugal}

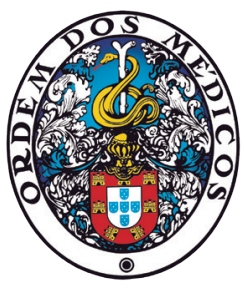

\author{
Joana LYRA ${ }^{1}{ }^{1}$, Rita VALENTE1, Marta ROSÁRIO², Mariana GUIMARÃES ${ }^{1}$
}

Acta Med Port 2020 Jun;33(6):429-431 $\cdot$ https://doi.org/10.20344/amp.13883

\author{
Errata/ Correction: \\ https://www.actamedicaportuguesa.com/revista/index.php/amp/article/view/14039
}

\begin{abstract}
We report the first cesarean delivery in a woman with COVID-19 in a level III hospital in Portugal. It refers to a healthy woman with a term pregnancy that tested positive for COVID-19 on the day of labor induction. Given a Bishop score < 4 and the prior history of a cesarean section, the team decided to perform a surgical delivery. Appropriate personal protective equipment and safety circuits were employed, as described in more detail in the case report. Both the mother and the newborn are well. With this report we aimed to share our concerns, clinical management, maternal and neonatal outcomes, and to present our current circuits and adjustments regarding the COVID-19 pandemic in our maternity hospital.
\end{abstract}

Keywords: Cesarean Section; Coronavirus; Coronavirus Infections; Pregnancy; Portugal

\section{RESUMO}

O caso apresentado diz respeito a uma grávida saudável, de termo, que teve o parto por cesariana num hospital nível III. Pela presença de contexto epidemiológico de risco, foi realizado o teste de pesquisa de SARS-CoV-2 que foi positivo no dia do internamento para indução do trabalho de parto. Dada a presença de um índice de Bishop < 4 e os antecedentes obstétricos, com uma cesariana anterior, foi decidido proceder à realização de um parto por cesariana. Durante todo o procedimento e contacto com a grávida foram utilizados dispositivos de proteção individual adequados e respeitados circuitos previamente definidos, que são descritos de seguida de forma mais pormenorizada. Quer a mãe, quer o recém-nascido encontram-se bem à data da descrição deste caso. Trata-se do primeiro parto por cesariana de uma grávida com COVID-19 em Portugal. Com esta publicação, o objetivo dos autores é apresentar as preocupações, orientação clínica face à presença de doença, os desfechos maternos e neonatais, bem como os circuitos definidos e as adaptações adotadas para dar resposta à situação atual de pandemia que vivemos.

Palavras-chave: Cesariana; Coronavírus; Infecções por Coronavírus; Gravidez; Portugal

\section{INTRODUCTION}

Severe acute respiratory syndrome coronavirus 2 (SARS-CoV-2) is the newest pandemic, recognized as so by the World Health Organization (WHO) on the $11^{\text {th }}$ March 2020. Since then, our knowledge about this new disease is increasing every day, but we still need more information in some specific populations, such as pregnant women and newborns. The disease comprises an acute respiratory symptomatology that can range from mild to critical, and often leading to death. Regarding pregnancy, the information is limited to small case series, mainly from China, ${ }^{1}$ where this pandemic began. It seems that pregnant women usually have mild disease and, according to most reports, there is no evidence of mother-to-fetus transmission. ${ }^{2}$ This case report refers to the first cesarean section performed at a level III hospital in Porto, one of the Portuguese Hospitals prepared to deal with cases of COVID-19 since the beginning of this pandemic.

\section{CASE REPORT}

This case refers to a healthy 35 -year-old woman [gravida 2, para 1 (cesarean section)], with a 39 weeks and six days uneventful pregnancy, that was admitted at a level III hospital for labor induction. She had informed the medical team that her grandparent had died the night before from COVID-19 and, despite not having had direct contact with him, she had close contact with the victim's caregiver (her mother). She reported only non-productive cough for three days. Considering the risk of COVID-19, we decided to test and admit her in order to induct labor. Testing for severe acute respiratory syndrome coronavirus 2 (SARS-CoV-2) was performed before starting labor induction (nasopharyngeal and oropharyngeal swabs). External cardiotocography showed fetal wellbeing and she stayed in an isolation room in the Obstetrics ward, previously defined as the most adequate location for women suspected of being infected to stay while awaiting the test result. All the health care professionals directly involved in the care provided wore appropriate, level 1 (1 pair of gloves, disposable gown, head cover, safety glasses/face shield, surgical mask or FFP1, shoe coverings) or 2 (2 pairs of gloves, disposable gown, head cover, safety glasses/face shield, N95 or FFP2 respirator, leg/shoe coverings) personal protective equipment (PPE), ${ }^{3}$ according to the suspicion level of infection in each moment. ${ }^{4,5}$

\footnotetext{
1.Department of Obstetrics. Centro Hospitalar Universitário de São João. Porto. Portugal.

2.Department of Neonatology. Centro Hospitalar Universitário de São João. Porto. Portugal.

$\triangle$ Autor correspondente: Joana Lyra. joanaritalyra@gmail.com

Recebido: 08 de abril de 2020 - Aceite: 20 de abril de 2020 | Copyright @ Ordem dos Médicos 2020
} 
While waiting for the result of the real time polymerase chain reaction (RT-PCR) test for SARS-CoV-2 she maintained occasional dry cough, without other respiratory symptoms or fever. She presented a good overall status, with normal peripheral oxygen saturation without need for oxygen therapy and without any symptom or sign of respiratory distress. She had spontaneous premature rupture of membranes 12 hours after admission; positivity for SARSCoV-2 was known almost at the same time. As she had had a former surgical delivery and maintained a Bishop score of $<4$, the team decided to perform a cesarean section rather than trying cervical maturation and labor induction.

She was transported from the isolation room to a specially designated operating theatre. The circuits between the ward and the operating theatre were previously defined in our internal protocols and well demarcated by color signs on the ground. Positive pressure inside the room was turned off. Nurses and doctors (obstetricians, neonatologists and anesthetist) were all equipped with level 2 PPE outside the operating room, and all the pathway leading from the isolation room to the operating room was sanitized.

Locoregional analgesia was performed followed by the cesarean section, without any intra-operative complications. The umbilical cord was immediately clamped, without neonate-maternal contact. The newborn was a male, weighting $3110 \mathrm{~g}$ and with an Apgar score of 8 in the $1^{\text {st }}$ minute and 9 in the $5^{\text {th }}$. The child was separated from the mother immediately after birth and placed in a single-patient negative pressure room. Newborn nasal and oropharyngeal swabs were collected at 0 hour, 48 hours and at $7^{\text {th }}$ day of life, all negative for SARS-CoV-2.

The mother completed the first 2 hours post-surgery inside the operating room where the cesarean section was performed and then she was moved to a ward dedicated to COVID-19 inpatients. She remained there for 48 hours, without any new respiratory symptoms or fever and with a normal postpartum evolution. During this period, she was monitored daily by infectious disease physicians and obstetricians, with evaluation of symptoms, signs and physical examination. She did not have any relevant changes in the blood tests performed. She started mechanical breast stimulation, in order to start breastfeeding after recovering from COVID-19. Placenta, amniotic fluid and colostrum were collected for future analysis and placenta was sent for histopathology.

She was discharged home at 48 hours post-partum, with indication to maintain isolation at home until recovery criteria were attained. At the moment of reporting, the newborn has been discharged home with his mother at day seven after birth, as she had already tested negative (two negative tests) for SARS-CoV-2. The mother returned at day 8 post- partum for surgical wound care. No complications related to the surgery were identified. She is currently breastfeeding.

\section{DISCUSSION}

This case represents the second delivery of a COVID-19 positive mother in our hospital. The first one concerned a woman who underwent vacuum extraction delivery without complications for both the mother and the newborn. COVID-19 is a highly contagious infection requiring planned intrapartum care for the safety of both patients and healthcare professionals. Nonetheless, we believe that the delivery route should be dictated by the obstetrical conditions, once the safe working conditions for all the intervening individuals are ensured, with appropriate personal protective equipment and planned circuits. In terms of postnatal care and given the conflicting data about pre and postnatal transmission, ${ }^{6,7}$ a multi-disciplinary team consensus comprising obstetricians, neonatologists and infectious diseases specialists at our institution decided on mother-neonate separation immediately after birth until both were tested negative for SARS-CoV-2. ${ }^{4}$

\section{ACKNOWLEDGMENTS}

We thank to all health care professionals across departments for being committed and trained in advance and in particular to Marina Moucho who were directly involved in this case.

\section{PROTECTION OF HUMANS AND ANIMALS}

The authors declare that the procedures were followed according to the regulations established by the Clinical Research and Ethics Committee and to the Helsinki Declaration of the World Medical Association.

\section{DATA CONFIDENTIALITY}

The authors declare having followed the protocols in use at their working center regarding patients' data publication.

\section{PATIENT CONSENT}

Obtained.

\section{COMPETING INTERESTS}

The authors have declared that no competing interests exist.

\section{FUNDING SOURCES}

This research received no specific grant from any funding agency in the public, commercial, or not-for-profit sectors.

pregnancy and delivery: rapid review. Ultrasound Obstet Gynecol. 2020 (in press). doi.org/10.1002/uog.22014.

3. Direção Geral de Saúde. Norma 007/2020. Prevenção e Controlo de Infeção por SARS-CoV-2 (COVID-19): Equipamentos de Proteção 
Individual (EPI), Orientação nº07/2020 de 29/02/2020. [accessed 2020/04/01], Available from: https://www.dgs.pt/directrizes-da-dgs/ normas-e-circulares-normativas/norma-n-0072020-de-29032020-pdf. aspx

4. Direção Geral de Saúde. Norma 018/2020. COVID-19: Fase de mitigação - gravidez e parto. Orientação no 018/2020 de 30/03/2020. [accessed 2020/04/01]. Available from: https://www.dgs.pt/directrizesda-dgs/orientacoes-e-circulares-informativas/orientacao-n-0182020de-30032020-pdf.aspx.

5. Royal College of Obstetricians and Gynaecologists. Coronavirus (COVID-19) infection and pregnancy. 2020. [accessed
2020/04/01]. Available from: https://www.rcog.org.uk/globalassets/ documents/guidelines/coronavirus-covid-19-virus-infection-inpregnancy-2020-03-09.pdf.

6. Zhu H, Wang L, Fang C, Peng S, Zhang L, Chand G, et al. Clinical analysis of 10 neonates born to mothers with 2019-nCoV pneumonia. Transl Pediatr 2020;9:51-60.

7. Chen H, Guo J, Wang C, Luo F, Yu X, Zhang W, et al. Clinical characteristics and intrauterine vertical transmission potential of COVID-19 infection in nine pregnant women: a retrospective review of medical records. Lancet. 2020;395:809-15. 